\title{
The Growth Prospect and Challenges of Financing Micro, Small and Medium Scale Enterprises (MSMEs) in Nigeria
}

\author{
B. O. Awoyemi, and A. A. Makanju
}

\begin{abstract}
This study identifies the growth prospect of financing Micro, Small and Medium Enterprises (MSMEs) in Nigeria and the challenges that constitute a hindrance to the growth of MSMEs in Nigeria. This study employed descriptive analysis, simple percentages and deductive method to describe the growth prospect of financing MSMEs and the problems experienced by the MSMEs. It was found that the growth and survival of MSMEs are still hampered by inaccessibility to funds owing to different reasons and challenges. The chief among the challenges is that financial institutions look at many MSMEs as high risk debtors without credit worthiness. The key finding of this study is that the financial support in term of loans given to MSMEs by the financial institutions has been declining continuously over the years and this hamper the growth prospect of MSMEs. The Federal Government should formulate policies that would encourage MSMEs to begin to source funds from the capital market through the introduction of the thirdtier security market since there is an increasing growth in the number of MSMEs in Nigeria.
\end{abstract}

Index Terms - Deposit money banks; Employment; Enterprises; Financing.

\section{INTRODUCTION}

In general, a lot has been said and written about The Micro, Small and Medium Enterprises (MSMEs) in the world and it has formed the subject of discussion scholars around the world. This is coupled with the fact that the governments of different nations have in one way or the other formulated and implemented policies aimed at improving the performance of MSMEs. They have received much attention because they act as job and wealth creators and they remain the major sources of innovation, technological development and entrepreneurship in developing countries.

MSMEs have been known, all over the world as an engine of economic growth and contributes to employment generation, wealth creation, poverty alleviation and food security [1]. The concept of Micro small and medium scale enterprises has been in existence since the 1940s. In Nigeria the history of MSMEs dated back to more than six decades ago during the colonial era in 1946 with a ten year development plan that targets to promote trade and industrialization [2].

The definition of MSMEs varies across countries; a small enterprise in the USA does not necessarily imply a small enterprise in Nigeria. The World Bank defines MSMEs as businesses with less than 300 employees, and $\$ 15$ million in assets. The Inter-American development bank describes MSMEs as businesses with maximum of 100 employees and less than \$3million revenue (Dalberg Global Development Advisors, 2011). According to Small and Medium Enterprises Development Agency of Nigeria (SMEDAN), MSMEs are classified based on the number of employees and the asset value which exclude the value of land and buildings. The summary of this definition is presented in Table I.

TABLE I: THE CLASSIFICATIONS OF MSMES IN NIGERIA [3]

\begin{tabular}{|l|l|l|}
\hline $\begin{array}{c}\text { The Category of } \\
\text { MSMEs }\end{array}$ & \multicolumn{1}{|c|}{$\begin{array}{c}\text { The Number of } \\
\text { Employees }\end{array}$} & $\begin{array}{c}\text { The Value of Assets } \\
\text { (N'M Excluding Land } \\
\text { and Buildings) }\end{array}$ \\
\hline Micro Enterprises & Less than 10 & Less than 5 \\
\hline Small Enterprises & $10-49$ & 5-Less than 50 \\
\hline Medium Enterprises & $50-199$ & 50-Less than 500 \\
\hline
\end{tabular}

From Table I, Micro Enterprises are businesses with total assets (excluding land and buildings) < N5 Million with a workforce not exceeding 10, while Small Enterprises are those whose total assets (excluding land and building costs) are above Five Million Naira but not exceeding Fifty Million Naira with a total number of workforces above ten, but not exceeding forty-nine. Medium Enterprises are those businesses with total assets (excluding land and building) are over N50 Million, but not exceeding N500 Million with a total number of employees between 50 and 199.

According to this definition, in the instance of a conflict on classification between employment and asset criteria, the employment-based will take priority. CBN in its 2005 guideline on small and medium enterprise investment scheme (SMEIS) describes MSMEs using asset criterion as any business that has a maximum capital base of 200 million Naira excluding loan and working capital with no upper or lower limit of staff. In Nigeria, the definition of MSMEs is more of an asset based than employee level based.

The Federal Ministry of commerce and industry describes MSMEs as businesses with total assets, which exclude the cost of land, but include capital cost up to N750, 000 and paid employment up to 50 people. However, the definition given by (SMEDAN) above is adopted since it bests describes the situation in Nigeria. MSMEs in Nigeria are seen as the backbone of the economy and the key source of economic growth and flexibility in the country.

However, the definition of MSMEs depends on the level of development of the country defining it. In most developed 
economies of the world like the United States of America, United Kingdom and Canada, the definition of MSMEs is based on the mixture of annual turnover and employment levels [4].

Other classifications of MSMEs relate to ownership structure. MSMEs can be in forms of sole proprietorships, or partnerships and some could even be registered as limited liability companies. Other common features of MSMEs in Nigeria include labour intensive production process; concentration of management on the key man; poor financial record keeping; Poor capital structure; low product quality output and high production cost due to inadequate infrastructure and wastages.

\section{Statement Of The Problem}

A key issue affecting the performance of the MSMEs in Nigeria is lack of easy access to funds. In Nigeria, about $80 \%$ of MSMEs are unproductive, because of poor financing. The federal government and the Central Bank of Nigeria (CBN) have tried to lessen the difficulties of funding by establishing many financial credit institutions so as to enable access to funds by the MSMEs.

However, the stringent conditions set by these institutions in addition to lack of adequate collateral and credit information have rendered this effort ineffective. Informal sources of finance still remain the major source of funding for MSMEs in Nigeria. This includes personal savings in addition to friends and family.

The formal financial institutions like Deposit Money Banks (DMBs) are still very unwilling to grant credit to MSMEs and the micro-finance banks have limited resources to go round. Other challenges faced in financing MSMEs in Nigeria are high interest rate, high inflation rate and exchange rate fluctuations. Some researchers held the believe that it is the uneconomic deployment of available resources by the owners that caused inadequate access to funds and that a lot of owners of MSMEs do take loans for business purposes but end up using it for personal purposes such as marrying new wives or travelling abroad.

These challenges have caused a large percentage of MSMEs to die within their fifth year of existence and another smaller percentage going to extinction within their sixth to the tenth year, leaving only about $5 \%$ of MSMEs to survive and grow in Nigeria [5]. All these factors reduce the funding available for financing MSMEs in Nigeria. This situation has greatly affected the growth potentials of MSMEs and much positive impact of MSMEs have not been felt in Nigeria, especially in the area of employment and self-sufficiency as compared to what is obtainable in the developed countries. It is on this note that this study aimed to identify the growth prospect of financing MSMEs and the major challenges of MSMEs in Nigeria.

\section{LITERATURE REVIEW}

\section{A. Overview of Government Intervention to Sustain MSMEs in Nigeria}

Different schemes have been implemented over the years by the government to increase the growth of MSMEs in
Nigeria and to meet the financial needs of these enterprises. Some of these schemes are highlighted and discussed as follows:

Micro, Small and Medium Enterprises Development Fund (MSMEDF, (2013).

This scheme was introduced in 2013 by CBN and established to increase women's access to financial services and to eliminate gender inequality via the Revised Microfinance policy, regulatory, and supervisory framework in which women's access to financial services is to be increased by at least $15 \%$ annually to eliminate gender disparity.

On this note, 60 percent of the fund was allocated for providing financial services to women. In 2013, N220 billion intervention funds were launched by the CBN to enable the MSMEs access fund for its growth. The government reduced the collateral requirement for the DMBs to access this intervention fund from 75 percent to 50 percent. This was done to enable the DMBs to have easy access to the fund for delivery to MSMEs at reduced interest rates. The Fund is to be given in the wholesale credit of $3 \%$ interest rate to the Participating Financial Institutions (PFIs) with a spread of $6 \%$, thereby bringing the lending rate to the maximum of $9 \%$ per annum inclusive of all charges for the MSMEs.

- The N200 billion Small and Medium Scale Enterprises Guarantee Scheme (SMECGS).

The scheme was established in 2010 to stimulate the development of the sector through increased access to credit by MSMEs. It guaranteed maximum amount of \#100 million in the form of working capital, long term loan for renovation or equipment upgrade. The scheme also delivers guarantees on loans by banks to absorb the risks that had inhibited banks from lending to the sector. The beneficiaries of the scheme are MSMEs in Nigeria.

- CBN Microfinance Policy, Regulatory and Supervisory Framework for Nigeria.

This was introduced by the government through the CBN in 2005. The policy provided the legal and regulatory framework for microfinance banking in Nigeria so as to create sustainable and credible microfinance banks that is capable of mobilizing and channelling funds to the MSMEs. However, this policy led to the conversion of all existing community banks into microfinance banks. Today, the microfinance banks provide partial financing medium to address the inadequate access to finance confronting the MSMEs in Nigeria.

- The Small and Medium Enterprises Equity Investment Scheme (SMEEIS)

This scheme is a voluntary initiative of the Bankers' Committee in 1999, but it was kick-started in 2001. The Scheme conditioned all banks to put aside $10 \%$ of their Profit after tax for equity investment and expansion of SMEs. The $10 \%$ is to be allocated to the MSMEs as the banking sector's support to the Federal Government's efforts towards stimulating economic growth through the development of MSMEs. The funding under the scheme is in the form of equity investment in qualified enterprises and loans at a single digit interest rate for the MSMEs. However, the scheme did not achieve the desired impact as most MSMEs were uninterested in the equity investment for fear of losing control of their businesses. 
Other Interventions include:

- The Youth Enterprise with Innovation in Nigeria (You Win) program.

- $\quad$ The Nigerian Incentive Based Risk Sharing System (NIRSAL, 2011) to financially support agricultural system.

- Small and Medium Enterprises Development Agency of Nigeria (SMEDAN) through the SMEDAN ACT 2003.

The Bank of Industry established in 2001 from the defunct Nigerian Industrial Development Bank and the Nigerian Bank for Commerce and Industry.

The National Economic Reconstruction Fund (NERFUND, 1989) established to spur the growth of MSME through medium and long term financing.

- $\quad$ The N100 Billion bond-funded Cotton, Textiles and Garment Industry Revival Scheme.

- $\quad$ Matching funds from big Entrepreneurs by BOI such as the N5 billion by Aliko Dangote

\section{EXTERNAL SOURCES OF FINANCING MSMES}

\section{A. Debt Financing}

Debt is external finance (formal and informal) employed in the business with obligation of regular interest payment and retirement of capital when the instrument crystallizes. The recognized debt financing sources of SMEs are; overdraft, trade credit, factoring, hire-purchase, leasing and term short and medium term loans from bank, national schemes/agencies introduced to aid SMEs such as Export Stimulation Loans (ESL) of the Central Bank of Nigeria, the National Directorate of Employment (NDE), National Poverty Eradication Program (NAPEP), and cooperative credit societies [6].

MSMEs are considered indigenous and informal, so obtaining finance from formal institutions is often difficult and this leaves them with other informal sources such as friends, associates and relations, clubs, trade credit, thrift and money lenders, which constitute a major source of more than $60 \%$ of total, owners' capital [7]-[8].

\section{B. Equity Finance}

Equity is an owner's investment in the form of capital in the business. Equity capital can be increased through retention of profit. It is often important as the take-off capital to meet capital and preoperational expenses [6].

Financial theory argues that borrowed fund is only appropriate for profitably operated businesses with the rate of return on investment higher than the cost of external funds. [9] discovered firms favour internally generated resources over the external capital, followed by [2] revealed that, the main sources of capital are personal savings with 54.4 percent, followed by loan with 22.0 percent. The family source of capital ranked third with 16.7 percent, while Cooperative/Esusu has $10 \%$.

\section{THEORETICAL ISSUES AND EMPIRICAL REVIEW}

Micro enterprises usually have a preference for short-term investment at low risk and are normally endowed with small amounts, whereas, small and medium enterprises have different preferences and need large capital accumulation. The extents of the banks' transformation services, improve the allocation of resources to sectors where the funds are most needed.

According to [9], financial intermediaries such as banks use economies of scale to transform households' savings into capital accumulation for enterprises. This method coupled with policy initiatives also reduces obstacles to capital allocation through the financial sector and thus improve the MSMEs efficiency which in turn stimulates economic growth. [11] provides the first wave of evidence on the finance and growth theory. This theory provided insights into the channels through which finance fosters economic growth.

Traditionally, finance has been connected to capital, a vital input and its accumulation as a prerequisite for sustainable growth. The traditional approach views financial intermediaries as being a bridge between the differences in interests between borrowers and lenders concerning the size of a financial investment, its maturity and risk. From the neoclassical point of view, growth is entirely driven by the accumulation of input factors and technical progress, with the potential role of finance classified to help in the accumulation of capital to sectors with adequate needs. According to the mainstream financial theory, it is expected that financial liberalization would facilitate access to finance and thus reduce the inability of the MSMEs to grow. However, the assumption that financial liberalization improves access to credit for MSEs does not stand up well to the experience of developing countries that face market imperfections and asymmetric information [12].

Evidences have shown that the small size of enterprises has a serious obstacle to access to finance. Enterprises need to grow in order to have further access to funds. Some studies such as [13]-[14] verified the assumption that financial liberalization improves access to credit for MSMEs in developing countries. However, [13] revealed that access to credit by Kenyan small and medium enterprises declined after liberalization, due to high nominal interest rates and high costs of other transactions.

In the same vein, [14] also found that in Bangladesh and Philippines, only small enterprises towards the upper end of the size distribution had viable access to formal sector finance. These perspectives lend credence to the growing insights into the operation of formal financial institutions and several government policies attempting to offer comprehensive financial service support for the growth of MSMEs with little significant effect.

In Nigeria, [15] identified the contributions of government and financial institutions in the growth of MSMEs. The study shows that most of the policies such as credit schemes, microfinance banks, CBN policies and Small and Medium Enterprises Development Agencies (SMEDAN) established to take care of the needs of MSMEs did not achieve much results because of poor implementation coupled with several cases of financial mismanagement by the benefiting enterprises and the administrators of loans. Similarly, [16] examined the challenges and prospects of MSMEs development in Lagos State, Nigeria. The study identified financial constraints and lack of management skill as major factors that hamper the growth of MSMES.

Moreover, in the evaluation of the challenges MSMEs in 
financing new or existing businesses in Gombe State, [17] revealed that the owners of MSMES are aware of the various sources of finance available to MSMES. [18] examined how MSMEs can be developed through the intervention of the banking sector. The study found that a positive correlation exists between loans grant by banks and the growth of MSMEs in Ekiti State. Equally, [19] expatiated on the growth, challenges and prospects of the MSMEs in the country. The work revealed that SMEs provide goods and services, create employment and improve standard of living. Overall, these views support the perception that financial intervention of financial institutions has significant contribution to the growth prospect of MSMEs in Nigeria.

\section{Methodology}

This section presents methodology which includes descriptive analysis with the aid of diagrams to analyze the data. Deductive approach was employed to draw conclusion from critically existing literatures and records. The data used in this study were secondary data from the financial statistics of the CBN Statistical Bulletin, and [20]. Also, the data cover information about the DMBs loan to MSMEs and total selfemployment as $\%$ of total employment as well as the total unemployment rate in Nigeria with the periods of 1992 and 2018.

\section{DISCUSSION OF FINDINGS}

\section{A. The Growth Prospect of Financing MSMEs in Nigeria}

Fig. 1 describes the DMBs loan to MSMEs as a percentage of DMBs total credit to the private sector. The DMBs financial supports to MSMEs over the years have been decreasing relative to the total financial credit given to the private sector. Between the 1992-1993 and 1994-1995 period, about $15 \%$ decrease in the loan given to MSMEs was recorded. From 1992 to 2016, there was a significant decrease of $22 \%$ in the DMBs loan to MSMEs relative to its total credit. This diagram shows a notable decrease in the financial loan received by the MSMEs from DMBs over the years. This is an indication that despite increased government Support to MSMEs, DMBs have reduced their support for MSMEs over time. This situation has significant impact on the growth of MSMEs. This implies that there have been little or no significant contributions from the financial institutions most especially from the DMBs to the development of MSMEs in Nigeria over the years. Although, the elimination of mandatory DMBs 'credit allocations of $20 \%$ of its total credit to MSMEs wholly owned by Nigerians took effect from October, 1996, yet decrease in the DMBs loan to MSMEs have been recorded prior to this period as shown in the diagram.

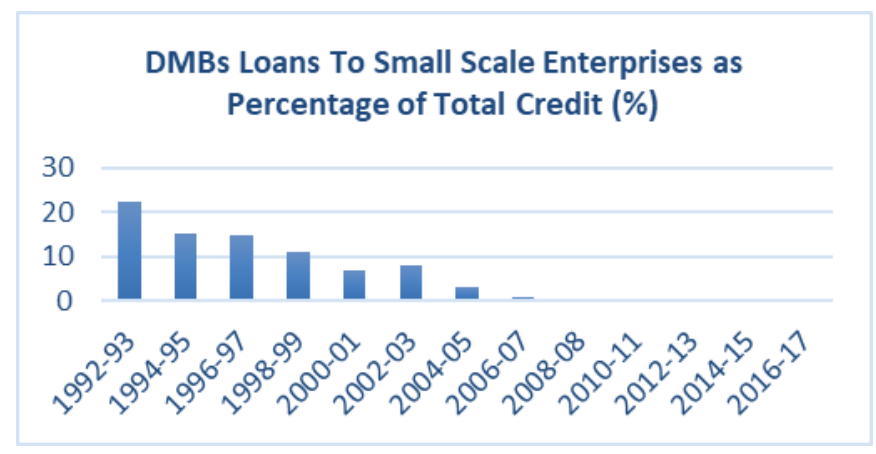

Fig 1. DMBs loan to MSMEs as a percentage of Total Credit.

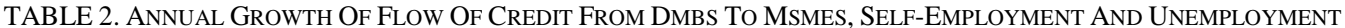

\begin{tabular}{|c|c|c|c|c|c|c|}
\hline & $\begin{array}{l}\text { DMBs Loans To } \\
\text { MSMEs }\left(\mathrm{N}^{\prime}\right. \\
\text { Million) }\end{array}$ & $\begin{array}{c}\text { Annual growth } \\
\text { (percent) }\end{array}$ & $\begin{array}{c}\text { DMBs Loans To } \\
\text { MSMEs as Percentage } \\
\text { of Total Credit }(\%)\end{array}$ & $\begin{array}{c}\text { Total Self- } \\
\text { Employment } \\
\% \text { of total } \\
\text { employment } \\
\end{array}$ & $\begin{array}{l}\text { Annual growth } \\
\text { (percent) }\end{array}$ & $\begin{array}{l}\text { Total } \\
\text { Unemployment } \\
\text { (ILO estimates) }\end{array}$ \\
\hline $1992-93$ & $17,931.5$ & - & 22.2 & 44.9 & - & 6.2 \\
\hline $1994-95$ & $26,463.5$ & 47.6 & 15.1 & 45.0 & 0.1 & 6.2 \\
\hline $1996-97$ & $41,573.2$ & 57.1 & 14.9 & 44.9 & -0.1 & 5.8 \\
\hline $1998-99$ & $44,542.4$ & 7.1 & 11.0 & 44.6 & -0.8 & 5.5 \\
\hline $2000-01$ & $48,485.4$ & 8.9 & 6.9 & 45.3 & 1.5 & 6.8 \\
\hline $2002-03$ & $86,272.5$ & 77.9 & 8.1 & 45.0 & -0.7 & 6.9 \\
\hline 2004-05 & $52,826.9$ & -38.8 & 3.1 & 39.8 & -11.6 & 7.0 \\
\hline 2006-07 & $33,407.1$ & -36.8 & 0.9 & 38.4 & -3.5 & 7.1 \\
\hline 2008-08 & $14,939.3$ & -55.3 & 0.2 & 37.0 & -3.5 & 7.2 \\
\hline $2010-11$ & $14,081.0$ & -5.7 & 0.1 & 36.0 & -2.7 & 7.3 \\
\hline $2012-13$ & $14,608.3$ & 3.7 & 0.1 & 35.1 & -2.5 & 7.3 \\
\hline 2014-15 & $14,509.4$ & -0.7 & 0.1 & 34.2 & -2.6 & 7.6 \\
\hline 2016-17 & $25,724.9$ & 77.2 & 0.2 & 33.7 & -1.5 & 5 \\
\hline
\end{tabular}


MSMEs through their employment generation and poverty reduction remain the key drivers of growth and development of the economy. Sustaining the growth of the SME sub-sector is very paramount in achieving sustained economic growth and development. Therefore, in sustaining the growth of SMEs, access to funding by SME operators has become critical, especially as these MSMEs have to rely on Deposit Money Banks and other financial institutions for investment financing. From the table 2, credit delivery to SMEs by the DMBs show fluctuating trend. From 2004-05 to 2010-11 periods, the annual growth rate of credit to MSMEs showed an average negative result of-38.8\%, $-36.8 \%-55.3 \%$ and $5.7 \%$ respectively. This result, support the view of earlier studies [21]-[22] that credit delivery to SMEs after the bank consolidation exercise reduced significantly. This is because, the surviving banks after consolidation became mega banks with big customers, thus the banks shift focus from lending to MSMEs to big customers with a quest to increase profits and as a result, the interest rate, which is a major source of profit for banks increased. Also, the banks are generally averse to giving credit to SMEs given the perception that the SMEs are very risky due to their lack of formal financial history and adequate collateral.

This situation has a significant effect on the growth of SMEs in Nigeria and it's also limit the prospect of MSMEs in generating employment and reducing poverty. It is crystal clear from the table, that the total self-employment as percentage of total employment significantly reduced starting from the period 2004-05 till 2016 while total unemployment rose during the periods. Specifically, in the period of the bank consolidation 2004-05 in which credit delivery to MSMEs fell, total self-employment as percentage of total employment was put at $39.8 \%$ with growth rate of $-11.6 \%$. This indicates a significant reduction in the percentage of self-employment in total employment. This may lend credence to the conclusion of past studies that the bulk of MSMEs business credit is primarily from banks and institutional changes in relation lending will likely have an effect on the MSMEs activities and performance

[23] clarified that SMEs account for more than $90 \%$ of all businesses outside the wage employment, thus, constituting a major source of employment and provides substantial domestic and export earnings in the OECD countries. In Nigeria, MSMEs were given more recognition due to increase in their numbers. Available data from the 2013 National MSME Survey show that the total number of MSMEs as of 2013 stood at 37,067,416 (Micro-36, 994,578, Small- 68,168, and Medium-4670).

The breakdown provided by National MSMEs collaborative survey 2010, shows that micro industries constitute about $99.87 \%$, the small enterprises accounted for about $0.12 \%$, while the medium scale enterprises are about $0.01 \%$ total number of MSMEs. The size of micro enterprises is larger than that of small and medium scale enterprises. This implies that most MSMES in Nigeria are micro enterprises. This huge gap is due to the fact that micro enterprises entails informal procedures such as little capital, less stringent registration conditions and frequent use of family members as members of staff with little or no pay for their services. Despite this increase in the number of micro enterprises in Nigeria, there has been no significant contribution to employment and poverty alleviation. For instance, in 2004 when a similar survey was conducted by the NBS, relative poverty stood at about $54 \%$, but in 2010 poverty level rose to $69 \%$; and by the NBS projection, it is expected to further increase in 2011. During the same period, unemployment was about $13.4 \%$ and has risen to $21.1 \%$ and $23.9 \%$ in 2010 and 2011 respectively [2].

TABLE 3. ThE CONTRIBUTION OF MSMES TO GDP AND EMPLOYMENT [2]

\begin{tabular}{|c|c|c|}
\hline Economy & $\begin{array}{c}\text { Contribution to } \\
\text { GDP }\end{array}$ & $\begin{array}{c}\text { Contribution to } \\
\text { Employment }\end{array}$ \\
\hline High Income & $55 \%$ & $65 \%$ \\
\hline Middle Income & $70 \%$ & $95 \%$ \\
\hline
\end{tabular}

MSMEs contribute more to employment than GDP across the global world. Table 3 shows that MSMEs contributes about $77 \%$ to employment while it's only contributes $62 \%$ to GDP. MSMEs contribute more to the economy of the middle income countries than the high and low income countries. However, in Nigeria, NMSMECS, (2010) showed that MSMEs contributed 46.54 percent to Nigeria's GDP in nominal terms. It also revealed that MSMEs made the highest contribution to other community, social, personal service activities followed by real estate, renting and business activities and agricultural activities while it contributes less to financial intermediation and building and construction. This is because the MSMEs are characterized by huge financing gap which hinders their development. The MSMEs globally are regarded as a catalyst for economic growth and continual employment generation as well as wealth creation. MSMEs have a tendency to employ more people than large enterprises, being labour-intensive in nature. Thus, MSMEs make a significant contribution to employment generation and expand industrial network and help to absorb productive resources at all levels of the economy. Also, the handcrafts and other products produced by this sector have good market demand. They also contribute significantly to generation of productive employment opportunities which can eventually reduce poverty and increase income level.

\section{Roles of MSMES in Nigeria}

MSMEs play significant contribution in the transition of agriculture-led to industrial economies by supplying basic prospects for processing activities which can generate a sustainable source of revenue and enhance the development process. The MSMEs are necessary in the development of the Nigerian economy as they play social and political role in the local employment creation, balance resource utilization, generate income, utilize local and domestic technology and raw materials. MSME therefore plays a crucial role in the progress of a country, most of the large scale enterprises in Nigeria and in the world at large have their beginning in MSMEs. The Micro, Small and Medium Enterprises are globally recognized as the oil lubricating the engine of socioeconomic transformation of any nation. The sector is structured across major sectors like Agriculture, Building and Construction, Mining and Quarrying, Manufacturing, among others and thus has strong linkages with the entire range of economic undertakings in the country. 


\section{B. Challenges of Financing MSMEs in Nigeria}

Despite the importance of MSMEs as a catalyst for economic growth and continual employment generation as well as wealth creation in the world, there has been an increasing rate of failure of MSMEs in Nigeria. Unfortunately, MSMEs in Nigeria have underperformed and are yet to make a significant contribution to the economic growth of the country owing to different reasons and challenges. These problems are highlighted and discuss as follows:

Inadequate Funding: The problem of lack of access to finance has hindered the contribution of MSMEs to economic growth. It affected their efficiency and secondary functions. The inability of MSMEs to meet the expectations of government in creating more jobs, increasing the production of goods and services, facilitating technology transfer, creating more opportunities for entrepreneurs and universal improvement of standard of living is due to lack of access to credit facilities. A significant numbers of MSMEs do not have access to formal sector funding and this hinders their growth and survival.

[24] noted that dearth of funds for MSMEs is their inability to raise external funding from financial institutions. This is because banks have always perceived MSME lending as high risk due to their informal nature, inability of these enterprises to prepare bankable business plans, lack of security required for conventional collateral based bank lending; and discriminatory cultural practices which hinders transparency. The existence of information irregularity arising from SMEs lack of accounting records, inadequate financial statements makes it difficult for banks to assess the creditworthiness of the potential MSMEs proposal. Also, [25] indicated that high interest rate constrained access to funding for MSMEs The combined effects of these factors make MSMEs financing an unprofitable business.

Management problems which include lack of manpower and training: Although there is no shortage of human resource, but the majority are semi-skilled and unskilled workers. Big firms employ skilled workers, while most of the MSMEs employ unskilled or semi-skilled workers. Skilled personnel like accountants and managers that are meant to be employed by MSMEs are not engaged partly due of financial problems [26]. Thus, MSMEs suffer from low managerial competencies. Also, the common problem of many micro businesses is poor leadership as many people go into businesses with inadequate knowledge or lack of entrepreneurial skills on how to run businesses in a bid to survive.

Inadequate infrastructure: The poor state of infrastructure in the country has been a hindrance to the growth of MSMEs. Only few businesses can survive without power supply. The epileptic power supply has contributed significantly to the high cost of doing businesses in the Nigeria. Infrastructural deficient includes inadequate energy supply, transportation problem and erratic water supply etc. Small firms cannot bear the cost of setting up independent power supply unit. Therefore, they have to depend on irregular power supply from the electricity boards.

Unstable policy environment: The perpetual change in government policies is another problem unsettling the growth of MSMEs in Nigeria. [27] explained that the inability of the government to make policies and implement them is a major constraint of MSMEs, and the end result of this is that it discourages investment.

Multiple taxation: MSMEs are subject to so many taxes and levies from the federal government to local government. So many agents are involved in the collection of taxes and levies. This has given room for unauthorized levies and taxes. The impact of this is on the operational costs of MSMEs cannot be overstated. The multiple taxation system has discouraged investment and impeded the growth of MSMEs in Nigeria. Government needs to streamline these taxes to help MSMEs.

\section{CONCLUSION AND RECOMMENDATIONS}

This study identifies the growth prospect of financing MSMEs and the challenges that constitute a hindrance to the growth of MSMEs in Nigeria. Despite the ability of MSMEs to contribute immensely to the GDP and employment opportunities, the growth and survival of MSMEs are still hampered by inaccessibility to funds owing to different reasons and challenges. The federal government and the country's Central Bank have tried to address the problem of inadequate funding by establishing many credit institutions to improve access to funding by the MSMEs. However, these initiatives appear not to be paying off as a percentage of DMBs loans to MSMEs relative to total credit to private sector keeps falling. This study identifies that many deposits money banks regard most of the MSMEs as high risk borrowers with no credit worthiness. Coupled with the above mentioned problem is the informal nature of most MSMEs as they are not duly registered enterprises and this makes financial institutions reluctant to give them loans. Unavailability of the collaterals which can be used in exchange for funds by the owners of MSMEs is also a major factor hindering the finance of MSMEs in Nigeria. If MSMEs in Nigeria are well financed, unemployment will significantly reduce via self-employment, especially among the youth.

This study further identifies that the conditions for accessing these loans still seem to be stringent. The DMBs have also been alleged to have increased the interest rates over and above the agreed amount stipulated under the Micro, Small and Medium Enterprises Fund (MSMEF) and most often are unwilling to give out loans to the informal sectors. Thus, most of these enterprises still suffer from financial constraints. All these factors corroborate with the key findings of the study that the financial support in term of loans given to MSMEs by the financial institutions has been declining continuously over the years. This study, therefore, suggests that the government should embrace policies that will encourage MSMEs to access funds from both the formal and informal sectors, especially the formal sector since the informal sector is believed to provide more than 70 percent of the funds to MSMEs. In addition to this, the federal government should formulate policies that would encourage MSMEs to begin to source funds from the capital market such as the introduction of the third- tier security market since there is an increasing growth in the number of small and medium enterprises. 


\section{ACKNOWLEDGMENT}

The authors acknowledge the support of the United Nations Economic Commission for Africa (UNECA) in providing facilities during the writing of this paper. The views expressed in this paper are those of the authors and do not represent that of the United Nations. The authors also acknowledge the support of John Awoyemi for proofreading this work and the staff of Economics Department, Afe Babalola University Ado-Ekiti, who provided comments to improve this work.

\section{REFERENCES}

[1] Aganga O. 'Government's Drive towards MSMEs Development in Nigeria'. 2013

[2] National MSME Collaborative Survey (NMSMECS) 'Survey Report on Micro Small and Medium Enterprises (MSMEs) in Nigeria. Collaboration between national bureau of statistics and small and medium enterprise development agency of Nigeria' (SMEDAN). 2010

[3] SMEDAN, 2007 National Policy on MSME, Web-site: www.smedan.gov.ng. May 2011.

[4] Agwu MO. "Organizational Culture and Employees Performance in the National Agency for Food and Drugs Administration and Control (Nafdac)," Nigeria. Global Journal of Management and Business Research. April 2014

[5] Abiodun, A., \& Harry, E. "SME firm's performance in Nigeria: Competitive advantage and its impact". International Journal of Research Studies in Management, 3(2), 75-86.2014.

[6] Akingunola RO. "Small and medium scale enterprises and economic growth in Nigeria: An assessment of financing options". Pakistan Journal of Business and Economic Review. 2011;2(1

[7] Abdulsaleh, A.M \& Worthington A.C. "Small and medium sized enterprise financing: A review of literature". International Journal of Business and Management, 8, 36-54, 2013.

[8] Ibrahim, M., Ibrahim, A. "The effect of SMEs' cost of capital on their financial performance in Nigeria". Journal of Finance and Accounting, 3, 8-11, 2015.

[9] Watse, D.U. "Sources of Financing for Small and Medium Enterprises in Nigeria". Walden Dissertations and Doctoral Studies Collection, 2017.

[10] Thiel, M. "Finance and economic growth- a review of theory and the available evidence". Journal of International Development J. Int. Dev. 18, 1017-1030. 2006

[11] King, R.G. and Levine. R "Finance, entrepreneurship, and growth theory and Evidence", Journal of Monetary Economics, Vol. 32 (1993), pp. 513-542, 1993.

[12] Green, C.J, C.H. Kirkpatrick and V. Murinde. "Finance for small enterprise growth and poverty reduction in developing countries" Journal of International Development. Vol.18, 1017-1030, 2006.

[13] Kariuki N. "The effects of liberalization on access to bank credit in Kenya". Small Enterprise Development 6(1): 15-23, 1995

[14] Meier R, Pilgrim M. "Policy induced constraints on small enterprise development in Asian countries". Small Enterprise Development 5(2): 32-38, 1994.

[15] Oni E.O and Daniya A. A. "Development of Small and Medium Scale Enterprises: The Role of Government and other Financial Institutions". Arabian Journal of Business and Management Review (OMAN Chapter) Vol. 1, No.7, 2012.

[16] Osotimehin, K.O, Jegede, C. A ,Akinlabi, B. H, Olajide, O.T. “An Evaluation of the Challenges and Prospects of Micro and Small Scale Enterprises Development in Nigeria". American International Journal of Contemporary Research Vol. 2 No. 4, 2012.

[17] Gulani M. G and Usman.A. "Financing Small and Medium Scale Enterprises (Smes): A Challenge for Entrepreneurial Development in Gombe State". Asian Journal of Business and Management Sciences. Vol. 2 No. 9, 17-23, 2013.

[18] Ayeni-Agbaje, A. R., Osho, A.E. "Commercial Banks Role in Financing Small Scale Industries in Nigeria (A Study of First Bank Plc. Ado-Ekiti, Ekiti State)". European Journal of Accounting Auditing and Finance Research. Vol.3(8); 51-76. 2015

[19] Ebitu,E.T., Basil,G., Ufot, J.A. “An Appraisal of Nigeria's Micro, Small And Medium Enterprises (MSMEs): Growth, Challenges and Prospects". International Journal of Small Business and Entrepreneurship Research .Vol.4(4); pp.1-15, 2016.

[20] World Bank. 2017. World Development Indicators 2017. Washington, DC. (C) World Bank. https://openknowledge.worldbank.org/handle/10986/26447 License: CC BY 3.0 IGO

[21] Mordi CN, Anyanwu CM, Adebusuyi BS, Odey LI, Amoo BA, Mbutor MO, Adebayo OM, Akpan NI, Igue NN, Ibeagha D, Belonwu M. "Credit delivery to small and medium enterprises: Post bank consolidation in Nigeria". Central Bank of Nigeria Occasional Paper. 2014 Oct; 53:1-76

[22] Okolo, C.V. "The Impact of Bank Consolidation on Lending to SMES in Nigeria. World Academy of Science, Engineering and Technology". International Journal of Economics and Management Engineering. Vol:9(9); 3166-3170, 2015

[23] Taiwo, J.N, Falohun, T.O.” MSMEs Financing and Its Effects on Nigerian Economic Growth". European Journal of Business, Economics and Accountancy Vol. 4(4), pp 37-54, 2016.

[24] Abeireijo J.O. and Fayomi A.O. "Innovative Approach to SME Financing in Nigeria: A Review of Small and Medium Indstries Equity Investment Scheme (SMIEIS)". Journal of Social Sciences, Obafemmi Awolowo University, Ile-Ife, Nigeria. 2005.

[25] Aliero, I.H \&Yusuf M.M. "Analysis of constraints to credit access for SMEs in Sokoto metropolis". Asian Journal of Economic Modelling. DOI: 10.18488/journal.8.2017.52.167.174. Vol. 5, No. 2, 167174.2017

[26] Abeh O. "The Problems and Prospects of Small and Medium Scale Enterprises (SMEs) Growth and Development in Nigeria: A Study of Selected SMEs in Delta State". International Journal of Scientific Research in Education, Vol. 10(3), 278-294. July 2017.

[27] Adekoya, A. Problems and prospects of SME's in Nigeria. [Online] Available: at;https://infoguidenigeria.com/problems-prospects-smesnigeria/ 2006.

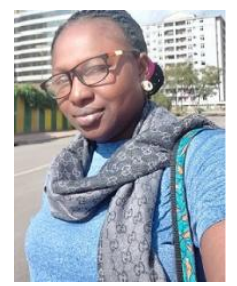

Dr. Awoyemi B.O. is currently a research fellow in the macroeconomics and governance division of the UNECA. She is also a lecturer in the department of Economics, Afe Babalola University Ado-Ekiti where she teaches microeconomics and macroeconomics related courses.

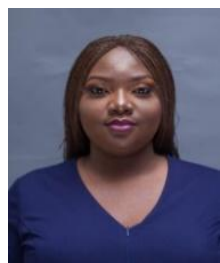

Aderonke A. Makanju is a research assistant at Lagos Business School. Prior to that, she was a lecturer at Afe Babalola University for over three years where she taught various courses in the department of Economics. With BSc and MSc in Economics, she is open to $\mathrm{PhD}$ opportunities in Strategy, Business and Management. 